\title{
DEVELOPMENT OF PREVENTING MEANS FOR RABBITS' COCCIDIOSIS
}

\author{
Oksana Shkromada \\ Department of therapy, pharmacology, clinical diagnostics and chemistry \\ Sumy National Agrarian University \\ 160 Herasym Kondratiev str., Sumy, Ukraine, 40021 \\ oshkromada@gmail.com \\ Oleksandr Skliar \\ Department of therapy, pharmacology, clinical diagnostics and chemistry \\ Sumy National Agrarian University \\ 160 Herasym Kondratiev str., Sumy, Ukraine, 40021 \\ sklyar1956@gmail.com \\ Andriy Paliy \\ Department of Technical Systems and Animal Husbandry Technologies \\ Kharkiv Petro Vasylenko National Technical University of Agriculture \\ 45 Moskovsky ave., Kharkiv, Ukraine, 61050 \\ paliy.andriy@ukr.net \\ Larysa Ulko \\ Department of therapy, pharmacology, clinical diagnostics and chemistry \\ Sumy National Agrarian University \\ 160 Herasym Kondratiev str., Sumy, Ukraine, 40021 \\ larisau@ukr.net

\section{Yulia Suprun} \\ Department of therapy, pharmacology, clinical diagnostics and chemistry \\ Sumy National Agrarian University \\ 160 Herasym Kondratiev str., Sumy, Ukraine, 40021 \\ ulianagerasimova@gmail.com

\section{Oleksandr Naumenko} \\ Department of Technical Systems and Animal Husbandry Technologies \\ Kharkiv Petro Vasylenko National Technical University of Agriculture \\ 45 Moskovsky ave., Kharkiv, Ukraine, 61050 \\ ol.naumenko@i.ua

\section{Katerina Ishchenko} \\ Department of Technical Systems and Animal Husbandry Technologies \\ Kharkiv Petro Vasylenko National Technical University of Agriculture \\ 45 Moskovsky ave., Kharkiv, Ukraine, 61050 \\ kaktjav@gmail.com

\section{Olesia Kysterna} \\ Scientific Consultant of Veterinary Clinic "Vet Service" \\ 12 A Pershotravneva str., Sumy, Ukraine, 40000 \\ Lesya_sumy2008@ukr.net \\ Oleksii Musiienko \\ Scientific Consultant of Veterinary Clinic "Vet Service" \\ 12 A Pershotravneva str., Sumy, Ukraine, 40000 \\ aleksey_musya@ukr.net
}




\author{
Anatoliy Paliy \\ Laboratory of Veterinary Sanitation and Parasitology \\ National Scientific Center «Institute of Experimental and Clinical Veterinary Medicine» \\ 83 Pushkinska str., Kharkiv, Ukraine, 61023 \\ paliy.dok@gmail.com
}

\begin{abstract}
The great problem of rabbits breeding today is coccidiosis. An agent of the disease spreads not only through ill animals and is preserved well in the external environment. Oocysts of coccidia live in cells for a long time, so even temporal vacation of an accommodation between placing of rabbits doesn't prevent infection. It was experimentally proved, that there is a very limited spectrum of means that are coccidiostatics. For preventing and controlling rabbits' eimeriosis, coccidiostatic means were tested. It is very difficult to annihilate coccidia in vivo and in vitro because of peculiarities of their construction. The aim of the first experiment was to determine the influence of an acidifier Cronocyde $\mathrm{L}$ and its components on oocysts of coccidia that allows to determine an optimal composition and concentration of the preparation. At conducting the research, there was used the flotation method of Fulleborn and McMaster one for calculating oocysts. The aim of the second experiment was to determine the influence of the acidifier Cronocyde L standard and Cronocyde L concentrate ( $1 \mathrm{ml} / 11$ of water) on the intensity of the living mass increment in rabbits. For that there were used clinical, hematological, zootechnical and microscopic methods. Optimal results in the experiment were obtained at using Cronocyde L concentrate and Cronocyde L standard in concentration 0,1\%: maximal growth and health status of rabbits, biochemical indices of blood serum were within the physiological norm. It testifies to the effectiveness of this preparation at eimeriosis of rabbits and to harmlessness for them. The studies, realized under laboratory conditions, prove the effectiveness of the offered means.

Keywords: coccidia, oocysts, eimeria, rabbits, coccidiostatics, water acidifier.
\end{abstract}

(C) Oksana Shkromada, Oleksandr Skliar, Andriy Paliy, Larysa Ulko, Yulia Suprun, DOI: 10.21303/2504-5679.2019.00914 Oleksandr Naumenko, Katerina Ishchenko, Olesia Kysterna, Oleksii Musiienko, Anatoliy Paliy

\title{
1. Introduction
}

Coccidioses are spread in all countries of the world and cause essential losses to animal husbandry. Climate conditions don't influence coccidian. It occurs in animals not depending on their age or race. Ill animals excrete oocysts that are a source of invasion with excrements, and transmission factors are forages, water, bedding, equipment of animal husbandry accommodations, servicing subjects and so on, polluted by them. Inflammation by coccidia is realized by the alimentary way as a result of swallowing oocysts with water or forage $[1,2]$.

The high vitality of cysts and oocysts of potozoa, eggs and larva of helminthes, ticks and insects and also their ability to survive after the contact with chemical substances in concentrations and expositions, destructive for pathogenic microorganisms, is a serious problem in the fight against invasive diseases of animals and humans. The stableness degree of oocysts of eimeria of pigs, ruminants, rabbits and poultry relates to the group of high-stable agents of parasitosis [3, 4].

Coccidiosis is one of oldest diseases in hares and wild rabbits, and although young individuals suffer more from it, adult rabbits that survived after it are permanent carriers of this disease all life long. The maximal risk zone includes rabbits that have already stopped to consume maternal milk, but have not achieved the age of four months yet. The danger of inflammation increases because of reconstruction of the not yet strong intestine for assimilating new forage $[5,6]$.

There are several factors that provoke the disease development; owners of animals must know about them:

- inobservance of quarantine at purchasing new rabbits that results in presence of ill animals in common cages;

- infected forage, purchased in fishy suppliers;

- appearance of other animals and insects that are spreaders of potozoa at the territory of cages;

- carelessness of the staff and careless construction of cages and enclosures;

- milk of a feeding female rabbit, infected by potozoa.

Such set of factors, provoking the epidemic, is explained very simply - coccidia must undergo two forms for the full-value development, one of which is an intrauterine stage that takes place 
in the intestine of an infected animal, and the other one - in results of animal life activity that is in excrements. If they are not removed in time, the possibility of inflammation of other individuals grows in several times $[7,8]$.

Clinical symptoms of intestinal and hepatic coccidiosis are very similar, it is difficult to distinguish them. Healthy rabbits often can be carriers of protozoa, but don't manifest symptoms of the disease. Its severity depends on a number of oocysts that get into the organism of a rabbit. Penetration of eimeria oocysts in the intestine and liver causes destruction of cells. Erosion and ulcer take place in the epithelial tunic of the intestine that results in bad absorption of nutritive substances, disturbance of electrolytic imbalance, anemia, dehydration of cells. General clinical signs include the appetite decrease, depression, pains in the belly, cachexy, diarrhea and anemia of mucous membranes. Faeces may contain blood or slime. Any one or all these signs may be absent in older rabbits $[9,10]$.

The aim of the first experiment was to determine the influence of an acidifier Cronocyde L and its components on oocysts of coccidia, that allows to determine an optimal composition and concentration of the preparation for annihilating oocystes of coccidia. At conducting the second experiment, the aim was to determine the influence of the acidifier Cronocyde L standard and Cronocyde L concentrate of the intensity on the dynamics of eimeria invasion, living mass increment in rabbits and biochemical indices of blood.

\section{Materials and Methods}

Experiment 1. Acids (components of the acidifier) were added in sterilized running water for getting $\mathrm{pH}$ 3,0-4,5. There were studied: orthophosphoric, formic, propionic, acetic, butyric, lemon, benzoic, sorbic acids. They were added in water at continuous measuring of $\mathrm{pH}$. $\mathrm{pH}$ was brought to the necessary level. The solution of acids with oocysts was incubated for 0,5 hours and 1 hour at $\mathrm{t} 25{ }^{\circ} \mathrm{C}$, taking into account the minimal time, in which the preparation can probably contact with oocysts of coccidia in the intestine of a rabbit. After that oocysts were fivefold washed, and samples were set for sporulation. Then the status of oocysts was studied. The analogous experiment was conducted with the ready acidifier Cronocyde L concentrate, produced by PE "Cronos Agro", Ukraine. Cronocyde L concentrate contains chelate of iron, manganese and copper, and also benzoic, acetic, propionic acids and marjoram extract. The preparation Cronocyde L standard contains thymol, formic, orthophosphoric, sorbic, lemon acids.

The diagnosis of eimeriosis was set according to results of the laboratory examination of rabbits' excrements by Fulleborn's method. The number of oocysts for a gram of excrements was determined by the McMaster method) [11, 12], and Eimeria times were identified using morphological criteria.

10-15 samples of oocysts were put in Petri dishes, and the working solution of the acidifier was added. At that there were gotten 11 experimental variants with different variants of $\mathrm{pH} 3.5-4.5$ and one control with water (Table 1). The Petri dishes with oocysts and $5 \mathrm{~cm}^{3}$ of distilled water were control.

Experiment 2. It was conducted on the vivarium of the Sumy National Agrarian University (city Sumy, Ukraine) from April to May of 2019. 5 laboratorially proved invaded repair females, treated for coccidiosis, were chosen for the studies. Young rabbits of these females were kept separately from other rabbits and were divided in three groups, ten individuals in each one: two depending on treatment scheme, one control. All rabbits were kept in equal conditions and get equal nutrition. All young rabbits during the experimental period were placed in three-floor cage batteries with sizes $3000 \times 650 \times 1800 \mathrm{~mm}, 5$ rabbits in each one, males and females separately.

The area of the floor of a cage for one rabbit was $0.25 \mathrm{~m}^{2}$, place for feeding $-60 \mathrm{~mm}$. Feeding took place two times a day - in morning and in evening. Rabbits were supplied with water by brooder water bowls with the preparation according to the treatment scheme.

Parameters of temperature, humidity and illumination corresponded to all norms and rules of rabbits keeping and were stable during the whole research period. The chosen cocciostatics were used for the first time on the husbandry base. The treatment of young rabbits 
was started at clinical manifestations of coccidiosis - emaciation, disorder of the esophagus, depression, after the laboratorial verification of invasion. Clinical observations were conducted from 1 to 21 day of the treatment. The level of eimeria invasion was determined microscopically by calculating the number of oocysts in the preparation before the treatment and for 7,14 and 21 day respectively. The treatment of rabbits was realized in the first group as Cronocyde L standard, in the second one (young rabbits) - Cronocyde L concentrate, third group - phyto-preparation Artemisia (tarragon extract-Artemisia annua). This phyto-preparation is a dry extract of granulated tarragon, easily soluble in water with bactericidal and coccidiostatic properties. In the experiment for rabbits it was dissolved in water and given as the solution of $0.05 \%, 0.1 \%$, $0.2 \%$ concentration. The control group didn't receive any coccidiosis treatment till the end of the research. Young rabbits didn't receive any prophylactic treatment, eimeriosis infection took place by the faecal-oral way because of the impossibility to provide hundred per cent sterility after invaded animals and high concentration of livestock at the farm. Clinical, hematological, zootechnical methods were used $[1,5]$.

\section{Results}

The study (experiment 1) for determining the influence of the acidifier Cronocyde L and its components on oocysts of rabbits' eimeria was conducted under laboratory conditions. At conducting the study, the condition of oocysts was estimated by the morphological signs (form, size, color, localization of the embryonic layer, presence of the polar granule and microfield). The research results demonstrated that oocysts of coccidia were influenced by all presented preparations: Cronocyde L standard and Cronocyde L concentrate and acids. But the effectiveness of their effect was different. The effectiveness of the preparations, namely death of oocysts, was expressed in per cents (Table 1).

Table 1

Effectiveness of coccidiostatics on oocysts of rabbits' eimeria

\begin{tabular}{|c|c|c|c|c|}
\hline No. & Active substance & pH & Exposition time & $\%$ of oocysts' death \\
\hline 1 & 2 & 3 & 4 & 5 \\
\hline \multirow{2}{*}{1} & \multirow{2}{*}{ Cronocyde L standard $1 \mathrm{ml} / 11$ of water } & \multirow{2}{*}{4.5} & $30 \mathrm{~min}$ & 15 \\
\hline & & & $60 \mathrm{~min}$ & 35 \\
\hline \multirow{2}{*}{2} & \multirow{2}{*}{ Cronocyde $\mathrm{L}$ standard $2 \mathrm{ml} / 11$ of water } & \multirow{2}{*}{3.5} & $30 \mathrm{~min}$ & 20 \\
\hline & & & $60 \mathrm{~min}$ & 60 \\
\hline \multirow{2}{*}{3} & \multirow{2}{*}{ Cronocyde L concentrate $1 \mathrm{ml} / 11$ of water } & \multirow{2}{*}{4.5} & $30 \mathrm{~min}$ & 60 \\
\hline & & & $60 \mathrm{~min}$ & 97 \\
\hline \multirow{2}{*}{4} & \multirow{2}{*}{ Cronocyde L concentrate $1 \mathrm{ml} / 11$ of water } & \multirow{2}{*}{3.5} & $30 \mathrm{~min}$ & 78 \\
\hline & & & $60 \mathrm{~min}$ & 99 \\
\hline \multirow{6}{*}{5} & \multirow{6}{*}{ Benzoic acid } & \multirow{2}{*}{3.5} & $30 \mathrm{~min}$ & 85 \\
\hline & & & $60 \mathrm{~min}$ & 98 \\
\hline & & \multirow{2}{*}{4.0} & $30 \mathrm{~min}$ & 60 \\
\hline & & & $60 \mathrm{~min}$ & 95 \\
\hline & & \multirow{2}{*}{4.5} & $30 \mathrm{~min}$ & 50 \\
\hline & & & $60 \mathrm{~min}$ & 90 \\
\hline \multirow{6}{*}{6} & \multirow{6}{*}{ Formic acid } & \multirow{2}{*}{3.5} & $30 \mathrm{~min}$ & 55 \\
\hline & & & $60 \mathrm{~min}$ & 80 \\
\hline & & \multirow{2}{*}{4.0} & $30 \mathrm{~min}$ & 30 \\
\hline & & & $60 \mathrm{~min}$ & 65 \\
\hline & & \multirow{2}{*}{4.5} & $30 \mathrm{~min}$ & 10 \\
\hline & & & $60 \mathrm{~min}$ & 24 \\
\hline
\end{tabular}




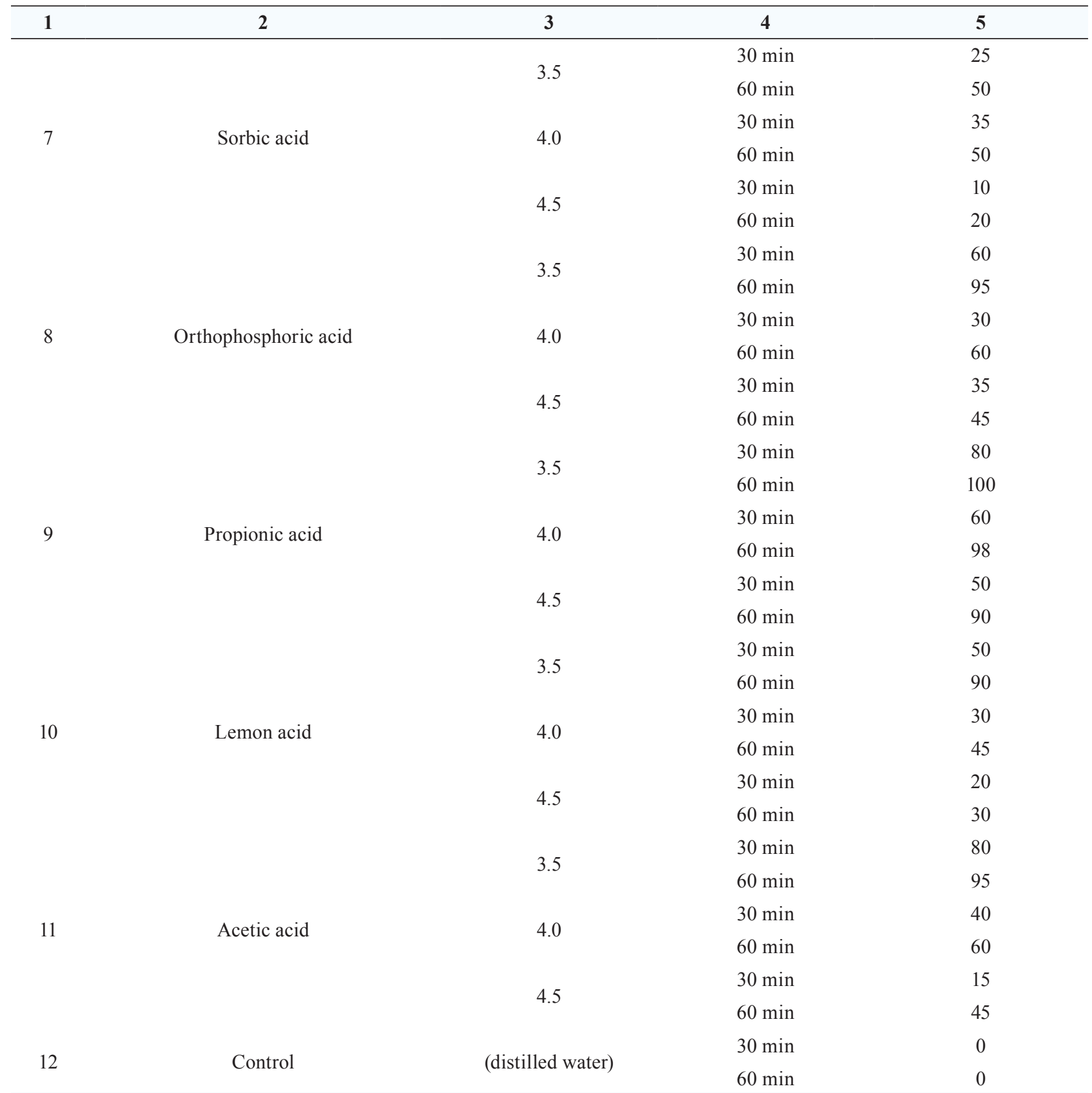

Thus, the highest results of oocysts' death was in the preparation Cronocyde 1 concentrate $\mathrm{pH} 3.5$, comparing to Cronocyde L standard. Such data were obtained due to the composition of the preparations. Cronocyde L concentrate includes benzoic, acetic and propionic acids that at $\mathrm{pH} 3.5$ and exposition 60 minutes caused death of 80-98 \% of oocysts. The effect of acids on the oocysts' tunic is conditioned by not only their concentration, but chemical construction that gives a possibility to penetrate the tunic of coccidia and to wrinkle a cytoplasm or to break it. The preparation Cronocyde L standard included formic, orthophosphoric, sorbic, lemon acids that at $\mathrm{pH} 3.5$ and exposition 60 minutes caused death of 50-90\% of oocysts. Normal pH of water for animal consumption is 3.5-4.5 and doesn't cause destruction of epithelium of the mucosa. The impossibility to increase or decrease $\mathrm{pH}$ of the preparations, because of using acidifier in rabbits, limits the effect. From the other side, it is necessary to create conditions, at which the ovocidal or coccidiostatic effect for coccidia is manifested. 
It is impossible to annihilate coccidia totally, that is an acidifier must be given every day with water, because at decreasing the therapeutic concentration of the preparation rabbits become ill. At the subclinical form of coccidiosis rabbits look completely healthy, but they consume less forage, become apathetic. Their weight and forage conversion decrease.

The obtained data are proved by the microscopic photos (Fig. 1-11).

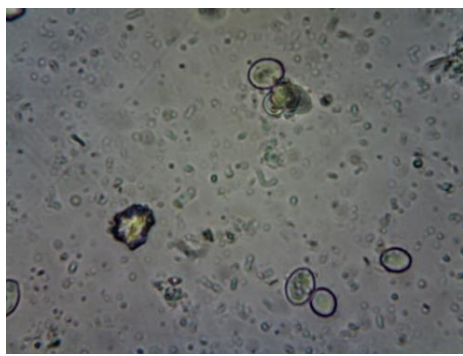

$a$

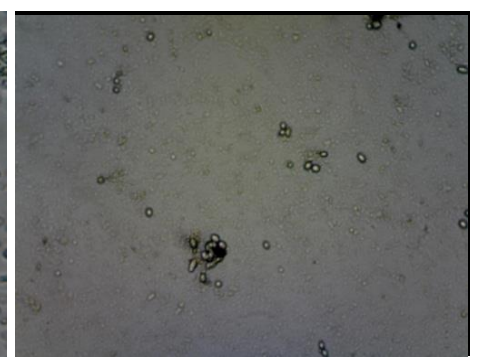

$b$

Fig. 1. Coccidia without adding a disinfectant: $a$-magnification $\times 1000 ; b$-magnification $\times 400$;

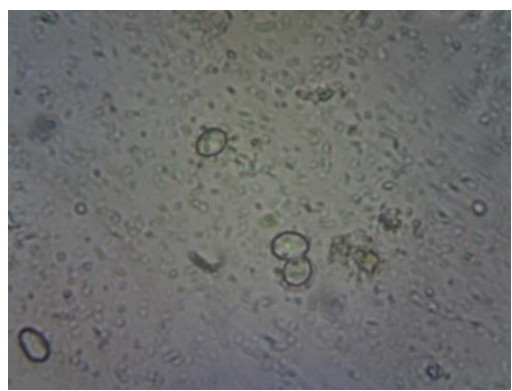

Fig. 2. Cronocyde L standard pH 3.5 - wrinkling of the cytoplasm of coccidia at exposition 60 minutes

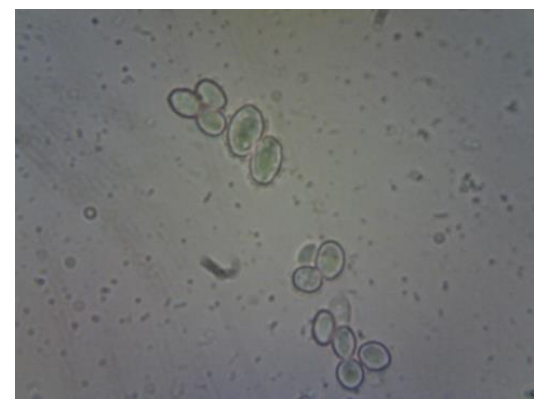

Fig. 3. Cronocyde L concentrate $\mathrm{pH} 4.5$ - wrinkling of the cytoplasm of coccidia at exposition 30 minutes

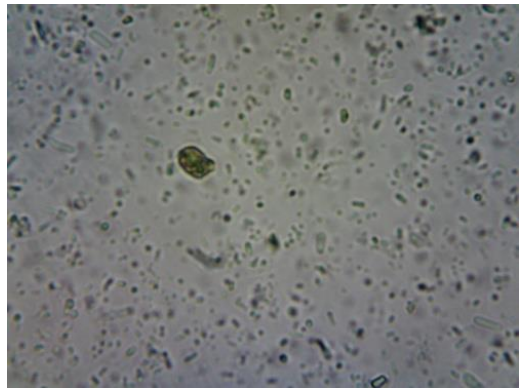

Fig. 4. Cronocyde L concentrate $\mathrm{pH} 3.5$ - wrinkling of the cytoplasm and break of the tunic of coccidia at exposition 60 minutes 


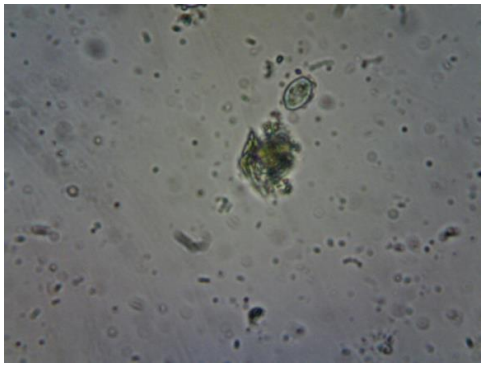

Fig. 5. Benzoic acid pH 4.5 - wrinkling and break of the cytoplasm of coccidia at exposition 30 minutes

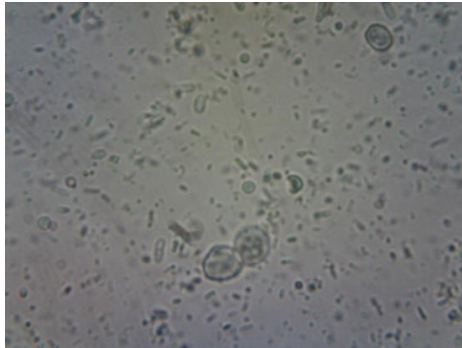

Fig. 6. Formic acid pH 3.5 - wrinkling of the cytoplasm of coccidia at exposition 60 minutes

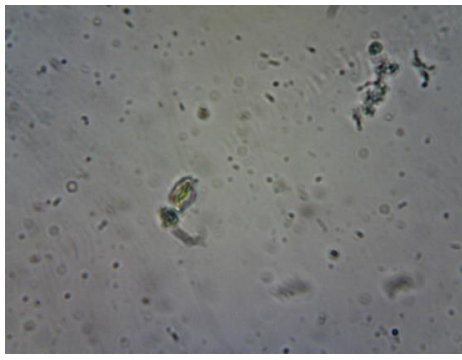

Fig. 7. Orthophosphoric acid $\mathrm{pH} 3.5$ - wrinkling and break of the cytoplasm of coccidia at exposition 60 minutes

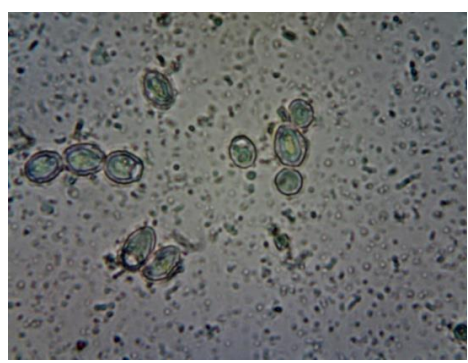

Fig. 8. Sorbic acid pH 3.5 - wrinkling of the cytoplasm of coccidia at exposition 60 minutes

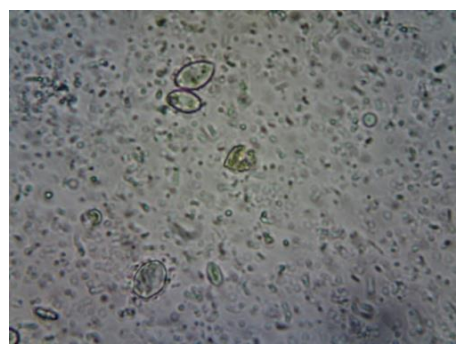

Fig. 9. Propionic acid pH 4.5 - wrinkling and break of the cytoplasm of coccidia at exposition 60 minutes 


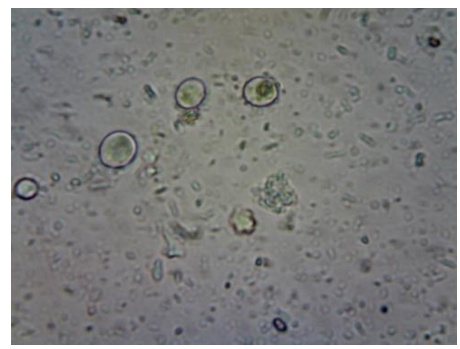

Fig. 10. Lemon acid pH 3.5 - wrinkling of the cytoplasm of coccidia at exposition 60 minutes

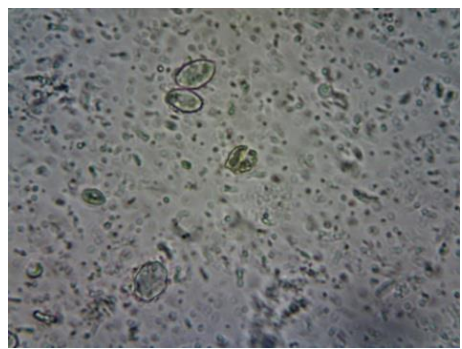

Fig. 11. Acetic acid pH 4.5 - wrinkling and break of the cytoplasm of coccidia at exposition 60 minutes

According to the results of the conducted studies, oocysts Eimeria stiedae, E. Perforans, E. Magna, E. Media were detected in rabbits' faeces. The research results (invasion extensiveness IE, preparation extensive effectiveness EE and lethality in the treatment period) are grouped in Table 2.

Table 2

Dynamics of eimeria invasion in rabbits

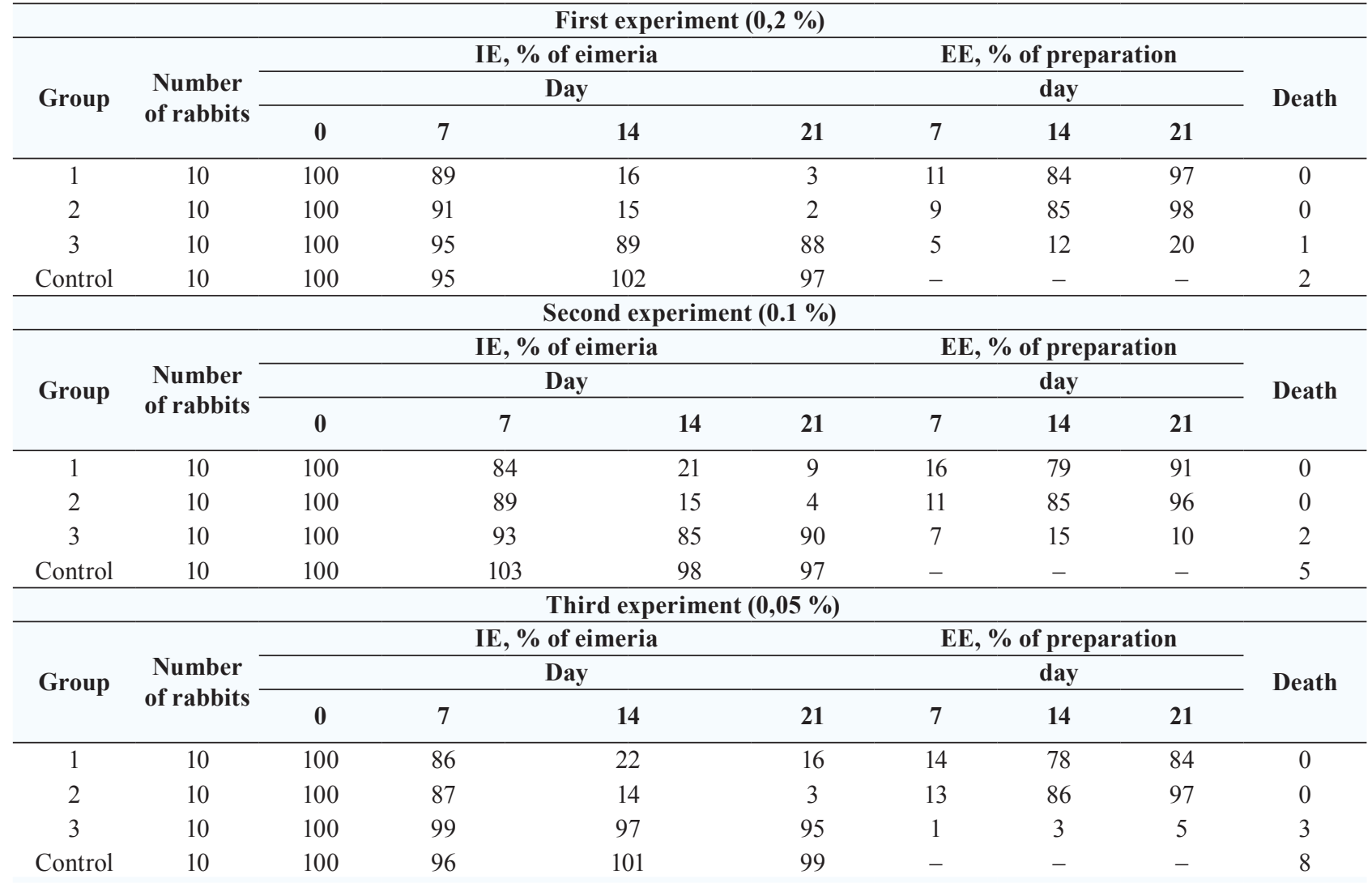


The research results testify that the extensive effectiveness of the preparation in the groups of rabbits decreased depending on concentration of the preparation and its properties. In rabbits of the third group, where the phyto-preparation Artemisia was used, the extensive effectiveness was very low during 21 days, possibly because of weak coccidiostatic properties of the preparation and high invasion extensiveness. Probably at increasing the concentration of Artemisia, the result can be improved, but then there appears a problem of toxicity and save term of usage. Frequent consumption of coccidiostatic, anti-helminth and bactericidal preparations results in allergic and immune-suppressive reactions. The hepatobiliary system is destructed at the unsystematic use of chemotherapeutic preparations for rabbits, especially in young individuals less 60 weeks old. At the beginning of the second experiment rabbits' invasion degree was high and reliably decreased to the 21 day of the study in the first group of rabbits, where Cronocyde L concentrate as 0.1$0.2 \%$ was used. There was revealed the maximal coccidiostatic effect due to effective components of this preparation, comparing with the control and Cronocyde L standard. It proves the previous laboratory studies in the first experiment.

For determining the effectiveness of the preparations Cronocyde L standard, Cronocyde L concentrate and phyto-preparation Artemisia as to coccidiosis and safety for rabbits, zootechnical parameters were studied.

10 animals-rabbit analogues with the initial weight 1,0 kg were used for the studies in each group. Rabbits were treated in the first group by Cronocyde L concentrate, young rabbits of the second group - by Cronocyde L standard, third group - by the phyto-preparation Artemisia, concentration $0,1 \%$. The results are presented in Table 3 .

Table 3

Comparative data of rabbits breeding

\begin{tabular}{|c|c|c|c|c|}
\hline \multirow{2}{*}{ Parameters } & \multirow{2}{*}{ Control } & \multicolumn{3}{|c|}{ Experimental groups } \\
\hline & & 1 & 2 & 3 \\
\hline Number of animals, ind. & 10 & & 10 & \\
\hline Initial living mass, $\mathrm{kg}$ & $1.0 \pm 0.13$ & $1.0 \pm 0.10$ & $1.0 \pm 0.10$ & $1.0 \pm 0.10$ \\
\hline Final living mass, $\mathrm{kg}$ & $1.5 \pm 0.45$ & $1.9 \pm 0.84$ & $1.8 \pm 0.72$ & $1.6 \pm 0.50$ \\
\hline Absolute increment, $\mathrm{kg}$ & $0.5 \pm 0.23$ & $0.9 \pm 0.95$ & $0.8 \pm 0.18$ & $0.6 \pm 0.18$ \\
\hline Average daily increment, $g$ & $16.4 \pm 1.34$ & $30.5 \pm 2.10^{*}$ & $27.6 \pm 2.53$ & $20.5 \pm 1.50$ \\
\hline Forage consumption, $\mathrm{kg}$ & 120.6 & 123.1 & 134.0 & 125.5 \\
\hline $\begin{array}{l}\text { Forage consumption for } 1 \mathrm{~kg} \text { of } \\
\text { the living mass increment, } \mathrm{kg}\end{array}$ & 1.57 & 1.66 & 1.64 & 1.67 \\
\hline$\%$ to the control & 97.5 & 100.5 & 98.8 & 102.5 \\
\hline
\end{tabular}

Note: * $-p \leq 0,05$ comparing with the control

As a result of the conducted studies, it has been established, that the average daily increment is more in the first experimental group by $18.5 \%$, in the second - by $15.6 \%$, and in the third - by $8 \%$. At conducting the experiment, there was determined the clinical status of rabbits. At that attention was paid to the forage conversion. The animals in the control consumed less forage than in the experimental groups.

The rabbits of the control group also demonstrated signs of coccidiosis, such as: exhaustion, swelling of the belly, apathy, absence of appetite, delay in growth and development, diarrhea and mucous extractions from the asshole. Most of these rabbits die even at treatment because of dehydration of the organism or injury of the liver. The results of the biochemical blood analysis of the experimental rabbits are presented in Table 4. 
Table 4

Biochemical analysis of blood serum at rabbits' eimeriosis

\begin{tabular}{ccccc}
\hline Parameters & 1 experimental group & 2 experimental group & 3 experimental group & control \\
\hline Total protein, g/l & $57.3 \pm 1.15$ & $66.9 \pm 0.92$ & $71.4 \pm 0.99$ & $41.6 \pm 0.81$ \\
Albumin, g/l & $39.1 \pm 0.72$ & $33.6 \pm 1.01$ & $29.9 \pm 1.52$ & $21.7 \pm 0.67$ \\
Thymol test, un. & $2.3 \pm 0.12$ & $3.3 \pm 0.28$ & $3.9 \pm 0.31$ & $2.4 \pm 0.27$ \\
Total bilirubin, mcmol/1 & $7.4 \pm 0.24$ & $10.5 \pm 1.19$ & $13.3 \pm 1.32$ & $31.2 \pm 0.63$ \\
Direct bilirubin, mcmol/1 & $2.4 \pm 0.15$ & $4.2 \pm 0.83$ & $4.0 \pm 0.56$ & $14.7 \pm 0.16$ \\
Indirectbilirubin, mcmol/1 & $5.1 \pm 0.35$ & $6.4 \pm 0.42$ & $9.1 \pm 0.81$ & $17.1 \pm 0.66$ \\
Urea, mmol/1 & $3.8 \pm 0.35$ & $7.5 \pm 0.51$ & $4.0 \pm 0.29$ & $24.4 \pm 0.56$
\end{tabular}

At appearing clinical manifestations there was observed the decrease of albumin and total protein in blood serum of rabbits from the second and third experimental groups and in the control. At injuring the liver by coccidia, bilious tracts are congested, mechanical jaundice appears. Autointoxication of the liver and hepatitis develop in an ill rabbit. The insufficient amount of bilious acids forms; and an animal can't digest food. That is why the level of albumins is low in blood serum of animals with coccidiosis. Bilirubin in blood of ill rabbits rises because of the same.

The level of direct bilirubin in the first experimental group is less by $6 \%$ in the second - by $1.8 \%$, in the third - by $1,6 \%$, comparing with the control group. There was observed the reduction of globulins in rabbits of the second and third experimental groups and in the control that is confirmed by the thymol test. The urea level in blood serum was less in the first experimental group comparing with the control one by $6,4 \%$, in the second - in 3,3 times, in the second - by $6.1 \%$. It testifies to the hepatorenal syndrome and renal function disorder.

\section{Conclusion}

The obtained results of annihilating coccidia at $\mathrm{pH}$ of the preparation within 3.5-4.5 in vitro under laboratory conditions gives a possibility to use this composition as a coccidiostatic for rabbits. It has been experimentally proved, that the preparation Cronocyde L concentrate reduces eimeria invasion, favors the rabbits' living mass increase and forage conversion. This composition essentially differs from the effect mechanism of most coccidiostatics and is not toxic that is proved by the results of the biochemical study of rabbits' serum. The preparation also improves digestion processes and inhibits the development of the conventionally pathogenic microflora, is an additional source of microelements.

At using the coccidiostatic for rabbits there was the short term of the experiment, so in further it is possible to conduct a more detail experiment. The special attention is planned to be paid to the creation term of coccidia forms, resistant to Cronocyde L.

The practical importance of the conducted experiments is in getting the effective and safe means - coccodiostatic and at the same time stimulator of metabolic processes for rabbits.

\section{References}

[1] Laha, R., Das, M., Goswami, A. (2015). Coccidiosis in rabbits in a subtropical hilly region. Indian Journal of Animal Research, 49 (2), 231. doi: https://doi.org/10.5958/0976-0555.2015.00064.3

[2] Papeschi, C., Fichi, G., Perrucci, S. (2013). Oocyst excretion pattern of three intestinal Eimeria species in female rabbits. World Rabbit Science, 21 (2), 77-83. doi: https://doi.org/10.4995/wrs.2013.1235

[3] Maziz-Bettahar, S., Aissi, M., Ainbaziz, H., Bachene, M. S., Zenia, S., Ghisani, F. (2018). Prevalence of coccidian infection in rabbit farms in North Algeria. Veterinary World, 11 (11), 1569-1573. doi: https://doi.org/10.14202/vetworld.2018.1569-1573

[4] Jing, F., Yin, G., Liu, X., Suo, X., Qin, Y. (2011). Large-scale survey of the prevalence of Eimeria infections in domestic rabbits in China. Parasitology Research, 110 (4), 1495-1500. doi: https://doi.org/ 10.1007/s00436-011-2653-4 
[5] Yin, G., Goraya, M. U., Huang, J., Suo, X., Huang, Z., Liu, X. (2016). Survey of coccidial infection of rabbits in Sichuan Province, Southwest China. SpringerPlus, 5 (1). doi: https://doi.org/10.1186/ s40064-016-2586-6

[6] Okumu, P. O., Gathumbi, P. K., Karanja, D. N., Mande, J. D., Wanyoike, M. M., Gachuiri, C. K. et. al. (2014). Prevalence, pathology and risk factors for coccidiosis in domestic rabbits (Oryctolagus cuniculus) in selected regions in Kenya. Veterinary Quarterly, 34 (4), 205-210. doi: https://doi.org/10.1080/016521 76.2014 .978044

[7] Silva, S. M., Ferreira, C., Paupério, J., Silva, R. M., Alves, P. C., Lemos, A. (2015). Coccidiosis in European rabbit (Oryctolagus cuniculus algirus) populations in the Iberian Peninsula. Acta Parasitologica, 60 (2), 350-355. doi: https://doi.org/10.1515/ap-2015-0049

[8] Saidj, D., Aliouat, S., Arabi, F., Kirouani, S., Merzem, K., Merzoud, S. et. al. (2013). La cuniculture fermière en Algérie: une source de viande non négligeable pour les familles rurales. Livestock Research for Rural Development, 25 (8). Available at: http://www.lrrd.org/lrrd25/8/said25138.htm

[9] Henneb, M. Aissi, M. (2013). Etude Cinetique de L'excretion Oocystale Chez la Lapine et sa Descendance et Identification des Differentes Especes de Coccidies. Proc. 15emesJournees de la Recherche Cunicole, 221-224. Available at: https://www.cuniculture.info/Docs/Magazine/Magazine2013/fichiers-pdfJRC/P02-Henneb.pdf

[10] Szkucik, K., Pyz-Łukasik, R., Szczepaniak, K. O., Paszkiewicz, W. (2013). Occurrence of gastrointestinal parasites in slaughter rabbits. Parasitology Research, 113 (1), 59-64. doi: https://doi.org/10.1007/ s00436-013-3625-7

[11] Ilic, T., Stepanovic, P., Nenadovic, K., Dimitrijevic, S. (2018). Improving agricultural production of domestic rabbits in Serbia by follow-up study of their parasitic infections. Iranian Journal of Veterinary Research, Shiraz University, 19 (4), 290-297. Available at: https://www.ncbi.nlm.nih.gov/pmc/articles/ PMC6361602/

[12] McMaster egg counting technique: Principle. Available at: https://www.rvc.ac.uk/review/ parasitology/EggCount/Principle.htm 